\title{
Xylogenesis of Scots Pine in an Uneven-Aged Stand of the Minusinsk Depression (Southern Siberia)
}

\author{
Marina V. Fonti ${ }^{a *}$, Elena A. Babushkina ${ }^{b}$, \\ Dina F. Zhirnova ${ }^{b}$ and Eugene A. Vaganovi,c \\ ${ }^{a}$ Siberian Federal University \\ Krasnoyarsk, Russian Federation \\ ${ }^{b}$ Khakass Technical Institute, Siberian Federal University \\ Abakan, Russian Federation \\ ${ }^{c} V . N$. Sukachev Institute of Forest SB RAS \\ FRC "Krasnoyarsk Science Center SB RAS" \\ Krasnoyarsk, Russian Federation
}

\begin{abstract}
Tree-ring formation studies are important for assessing the impact of environmental factors on tree growth at intra-seasonal resolution. This information is necessary for understanding plant acclimatization to current and expected climate changes. Little is still known about how tree age may affect the duration and rate of annual ring formation. In this study, we investigated tree-ring formation in Scots pine (Pinus sylvestris L.) trees of different ages (30- and 95-year-old trees) from the foreststeppe zone in Southern Siberia. The main objectives were 1) to estimate the timing of cambial activity by distinguishing the phases of division, enlargement, wall thickening, and maturation of tracheids and 2) to compare the anatomical structure of the tracheids forming the annual rings of the differently aged trees. Stem tissue was sampled weekly from April to September 2014. The results showed a 1-2 week difference in duration of the phases of xylem formation between the groups; in addition, the ring width of the young trees was slightly narrower. The size of the tracheids of the entirely formed ring (i.e. the results of the enlargement phase) did not differ between the groups whereas the dynamics of the cell-wall thickness showed significant differences. The data obtained in the present study can provide references to calibrate process-based models linking environment to wood formation. These data can be used to benchmark time-explicit simulated measurements of annual ring increment and cell anatomical structure against the corresponding parameters of mature trees growing under natural conditions.
\end{abstract}

(C) Siberian Federal University. All rights reserved

This work is licensed under a Creative Commons Attribution-NonCommercial 4.0 International License (CC BY-NC 4.0).

* Corresponding author E-mail address: mbryukhanova@sfu-kras.ru ORCID: 0000-0002-2415-8019 (Fonti M.); 0000-0002-1355-4307 (Babushkina E.); 0000-0002-5189-5700 (Zhirnova D.); 0000-0001-9168-1152 (Vaganov E.) 
Keywords: Pinus sylvestris, xylem, cambial activity, radial tree-growth, wood anatomical features.

\title{
Особенности ксилогенеза сосны обыкновенной
}

\section{в разновозрастном древостое \\ Минусинской котловины (Южная Сибирь)}

\author{
М.В. Фонти ${ }^{a}$, Е.А. Бабушкина \\ Д.Ф. Жирнова ${ }^{\tilde{\sigma}}$, Е.А. Ваганов ${ }^{\mathrm{a}, \mathrm{B}}$ \\ ${ }^{a}$ Сибирский федеральный университет \\ Российская Федерация, Красноярск \\ ${ }^{6}$ Хакасский технический институт, филиал \\ Сибирского федерального университета \\ Российская Федераиия, Абакан \\ ${ }^{6}$ Институт леса им. В.Н. Сукачева СО РАН \\ ФИЦ «Красноярский научный иентр СО РАН» \\ Российская Федерачия, Красноярск
}

\begin{abstract}
Аннотация. Исследования сезонного формирования ксилемы годичных колец деревьев позволяют оценивать влияние факторов среды на рост древесных растений с высоким временным разрешением и скорость их адаптации к текущим и ожидаемым изменениям климата. Все еще недостаточно изученным является вопрос, как возраст деревьев может влиять на скорость их роста и продолжительность ксилогенеза. В связи с этим целью нашего исследования было установить особенности сезонного формирования годичных колец сосны обыкновенной (Pinus sylvestris L.), произрастающей в зоне лесостепи Южной Сибири, для деревьев двух возрастных групп (30 и 95 лет) и получить данные о продолжительности камбиальной активности, растяжении трахеид, утолщении их клеточной стенки и появлении зрелых трахеид в кольце, а также сопоставить анатомическую структуру образованных годичных колец у деревьев разного возраста. Отбор сезонных образцов проводили еженедельно в течение 2014 г. с апреля по сентябрь. Результаты исследования показали, что длительность различных фаз формирования ксилемы у этих групп отличалась на 1-2 недели, при этом в течение сезона роста у молодых деревьев сформировалось более узкое кольцо с меньшим числом клеток по сравнению со старыми деревьями. Радиальные размеры трахеид полностью сформированного кольца у двух групп деревьев оставались практически одинаковыми, тогда как динамика толщины клеточной стенки показала значимые различия. Полученные данные могут быть использованы в дальнейшем как входящие параметры имитационных моделей роста древесных растений и позволят получить биологически обусловленную согласованность между измеренной и имитационной величинами годичного прироста и анатомической структуры ксилемы.
\end{abstract}


Ключевые слова: Pinus sylvestris, ксилема, камбиальная активность, радиальный прирост деревьев, анатомические параметры древесины.

Цитирование: Фонти, М.В. Особенности ксилогенеза сосны обыкновенной в разновозрастном древостое Минусинской котловины (Южная Сибирь) / М.В. Фонти, Е.А. Бабушкина, Д.Ф. Жирнова, Е.А. Ваганов // Журн. Сиб. федер. ун-та. Биология, 2020. 13(2). С. 197-207. DOI: 10.17516/1997-1389-0323

\section{Introduction}

The effect of short-term climatic fluctuations (including weather anomalies) on the tree-ring growth and productivity of tree species can be assessed using xylogenesis observations performed at a weekly resolution over the growing season (Lobzhanidze, 1961; Vaganov, Shashkin, 2000; Antonova, Stasova, 1997; Vieira et al., 2009; Cuny et al., 2015; Rathgeber et al., 2011). Such observations provide time-explicit ecophysiological information on the process of growth, linking physiological processes (photosynthesis, transpiration, accumulation and redistribution of carbohydrates, etc.) to structural and functional changes in xylem and enabling analysis of a wide range of factors influencing plant growth with high temporal resolution (Rinne et al., 2015; Steppe et al., 2015; Churakova et al., 2016; Fonti et al., 2018). These data are needed to understand current and to predict expected multi-parameter tree-growth responses to climate change.

To correctly interpret the environmental variability of growth responses to environmental changes, it is also important to investigate the effects of ontogenetic processes on tree-ring formation dynamics. For example, little is still known about the effect of age on the rate and duration of tree growth (different phases of xylem formation). The few previous studies reported that under equal environmental conditions, young trees have an earlier onset and a longer duration of each phase of xylogenesis compared to the old trees (Rossi et al., 2008). Therefore, young trees usually form a greater number of cells during the growing period, are more sensitive to drought, and more easily form intra-annual density fluctuations (Rossi et al., 2008; Kishchenko, 2014; Campelo et al., 2015; Vieira et al., 2018; Popkova et al., 2018). The discrepancy in the timing of the different phases of xylem formation might cause variations in the climate signal recorded by different parameters of the tree ring such as the ring width, the cell anatomical structure, and the intra-annual wood density (Connor, Lanner, 1990; Vaganov, Shashkin, 2000).

The aim of this study was to estimate the differences in the timing and rate of intra-annual xylem formation in young (30 year-old) and old (95 year-old) Scots pine trees growing in the forest-steppe zone of Southern Siberia (Russia). By quantifying the timing of cambial activity, we also determined the onset and cessation of different phases of tracheid formation such as the division, enlargement, wall thickening, and maturation and estimated impact of these processes on the anatomical parameters of tracheids forming the tree rings. Two groups of trees of different ages were compared.

\section{Materials and Methods}

The study area is located in the forest-steppe zone of Southern Siberia, close to the city of

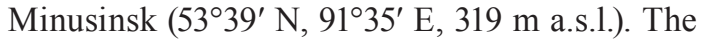
uneven-aged Pinus sylvestris L. stand is part of the pine forest band of the Minusinsk Depression (Fig. 1). The stand understory is composed of shrubs (Caragana arborescens Lam., Cotoneaster melanocarpus Fisch. ex Blytt., Rosa acicularis 


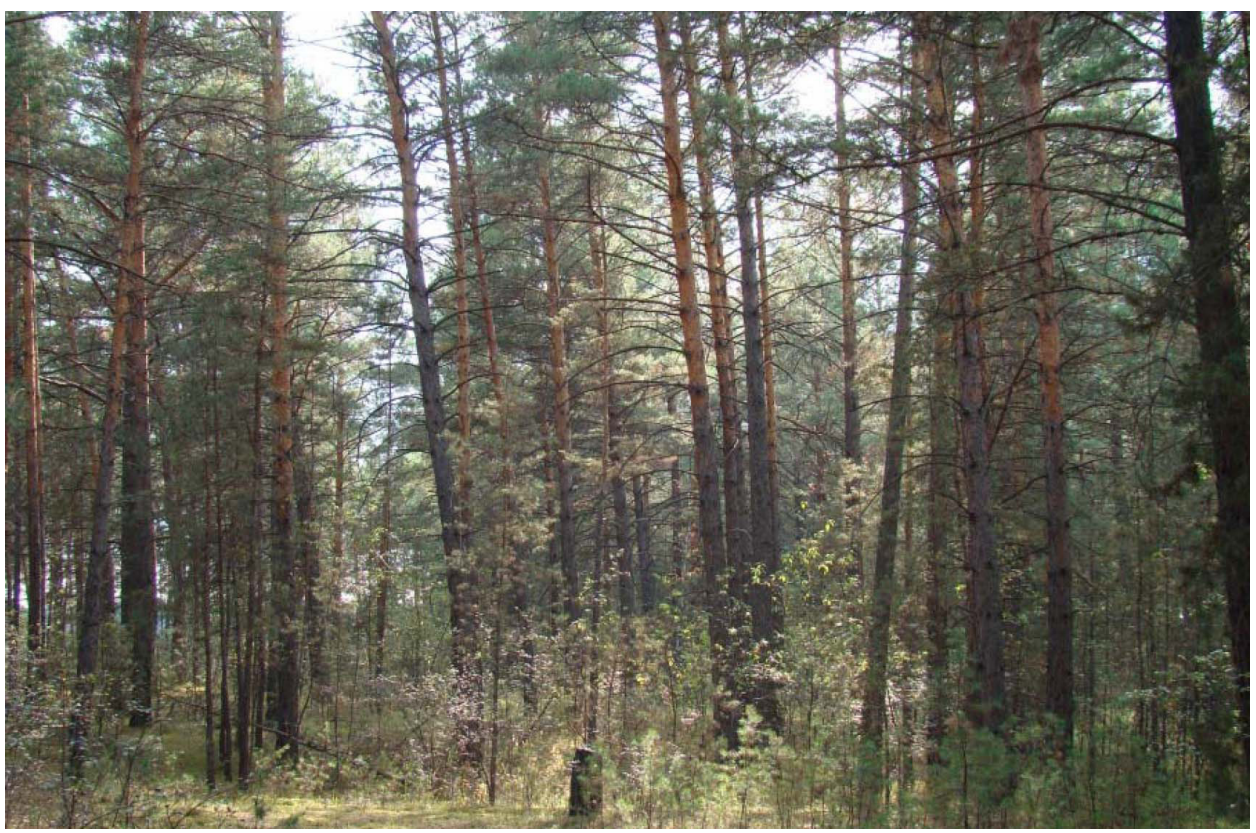

Fig. 1. A photograph of the study stand

Lindl.) - 30\%, and grasses (Iris ruthenica Ker.Gawl., Phleum phleoides (L.) H. Karst., Poa pratensis L., Pulsatilla flavescens (Zucc.) Juz., Thalictrum minus L.) - 40-50\%. The climate is continental with an annual air temperature of $1.2{ }^{\circ} \mathrm{C}$ and the total annual precipitation of $343 \mathrm{~mm}$ (data are retrieved from the Minusinsk Meteorological Station of the Russian Research Institute of Hydrometeorological Information for the period of 1936-2015 (https://meteo.ru)).

To monitor tree stem radial growth, wood cores $5-\mathrm{mm}$ in diameter were collected perpendicular to the stem axis at breast height from 20 dominant and co-dominant pine trees with regular growth and equally distributed between two age groups. Annual tree-ring width (TRW) was measured on each core using a LINTAB measuring table combined with the TSAP program (Rinntech, Heidelberg, Germany) with $0.01 \mathrm{~mm}$ precision (Rinn, 1996). The timeseries obtained were visually cross-dated, and dating quality was verified using the COFECHA program (Holmes, 2001). Five trees per age group
(30 and 95 year-old ones) were chosen for further xylogenesis observations.

Stem wood samples about $1 \mathrm{~cm}$ long (including two-three annual rings of the preceding growth years) were taken from the five young and five old trees weekly from the beginning of April to mid-September in 2014 using a Hagloff increment borer (Sweden). Samples were taken following a spiral pattern around the trunk at $5 \mathrm{~cm}$ apart starting at breast height. After collection, samples were immediately placed into cylindrical containers with a glycerin-alcohol-water fixing fluid (1:1:1). In total, seasonal wood samples were collected 20 times over the growing period.

From each sample, a $15 \mu \mathrm{m}$-thin microsection was cut with a Thermo Scientific Microm HM 450 sledge microtome. Sections were stained with $2 \%$ astra-blue and $1 \%$ safranin solution to enhance contrast between lignified and unlignified tissues. The sizes of different zones of rings and the number and size of cells were measured using an image analysis system (Carl Zeiss, Jena, Germany) and AxioVision 
SE64 Rel. 4.9.1 software package, which made it possible to determine the parameters of cell structure in different parts of an annual ring in a semiautomatic mode. Three tracheid radial rows (from the internal towards the external tree-ring boundary) were measured for each annual ring and the values were then averaged.

The cells were assigned to the following developmental zones: (1) cambial zone; (2) cell extension zone; (3) zone of primary cell wall lignification; and (4) mature tracheid zone. The polarization filter was used to discriminate between the cell extension zone and the zone of primary cell wall lignification.

Tracheid anatomical parameters were measured in the last collected sample, which included all mature tracheids formed during the 2014 growing season. Five radial rows of cells with the largest cross-sectional area were selected. The radial lumen diameter (LD) and double cellwall thickness (2CWT) were measured and then used to calculate the radial size of tracheids $(D=\mathrm{LD}+2 \mathrm{CWT})$. According to Mork's index (Denne, 1989), the ratio between the width of the double cell wall and lumen diameter was used to assign the tracheids to early (EW, 2CWT $<\mathrm{LD}$ ) and late wood (LW, 2CWT $>$ LD) of each ring. Because of the different numbers of cells within the annual rings of the young and the old trees, cell number (cell-wall thickness and cell radial diameter) was standardized to a common number (15) to compare the same ring sectors between two groups (Vaganov, 1990; Babushkina et al., 2019). The significance of differences of anatomical parameters between the two groups was estimated using Student's $t$-test.

\section{Results}

The cambial zone of the trees included five to seven cells during their dormant period (in spring and autumn) (Fig. 2A). The beginning of the cambial activity, as observed on the xylem side, occurred simultaneously in both groups on April 11 (Day 101 of the year (DOY)). The duration of the cambial activity was 110 days, and there were 10 dividing cells within the zone, on average. The maximum activity was observed two weeks earlier for younger trees than for older trees (May 18 and June 2, respectively); the first cells were detected in the enlargement zone at the same time (Fig. 2B). At the end of July, the cambial activity stopped. Cell enlargement in younger trees ended two weeks earlier than in the older ones.

The emergence of cells in the cell-wall thickening and the primary lignification zones was observed on May 8 (DOY 128) for young trees and on May 16 (DOY 136) for old trees, reaching the maximum on August 7 and 28 for young and old trees, respectively. On the last sampling day (September 18), two young trees out of five did not finish cell-wall lignification, whereas all old trees had already completed xylem formation.

Mature tracheids with the fully formed secondary cell wall were observed in pine earlywood of both age groups simultaneously, at the beginning of June. The maximum number of cells (up to 60) was counted for trees of the old group. However, the percentage of the mature tracheids relative to the total cell number within the tree ring was higher for the young trees, reaching $80 \%$ as early as the beginning of August (Fig. 3).

The mean tree-ring width in the young and old trees for the period from 1985 to 2014 was 2.34 and $1.41 \mathrm{~mm}$, respectively. Ring width dynamics in the young trees was similar to the ring width dynamics in the old trees when they were of the same age (Fig. 4A). The range of ring widths was also comparable between the groups at similar ages (Fig. 4B). Periods of 1962-1965 and 1975-1977 were characterized by dry conditions (Kostyakova et al., 2018), which significantly affected the old trees (Fig. 4A). The absence of fire scars suggests that the selected trees were not 


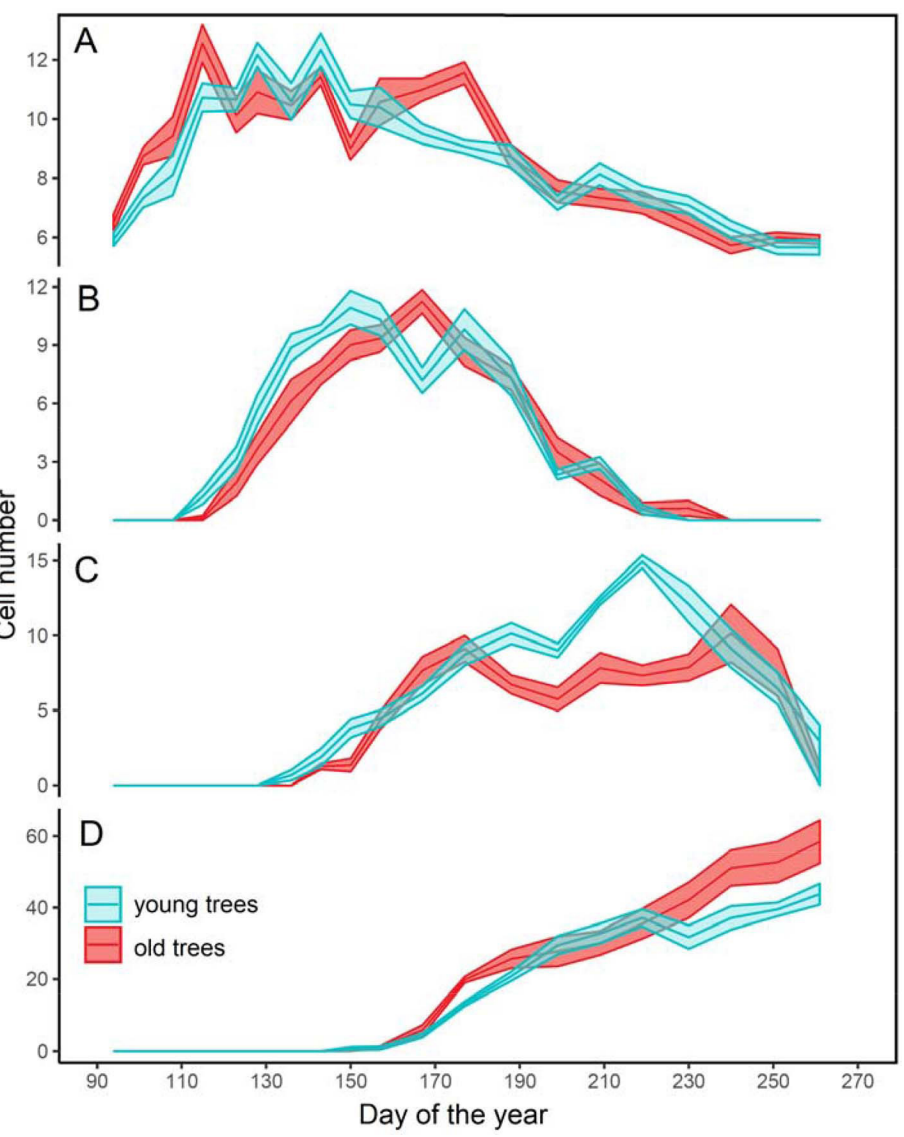

Fig. 2. Mean cell number ( \pm standard error) of the different zones of the developing tree ring: $A$ - cambial zone; $B$ - zone of enlarging cells; $C$ - cell-wall thickening zone; $D$ - zone of the mature cells. Blue is young trees, red is old trees

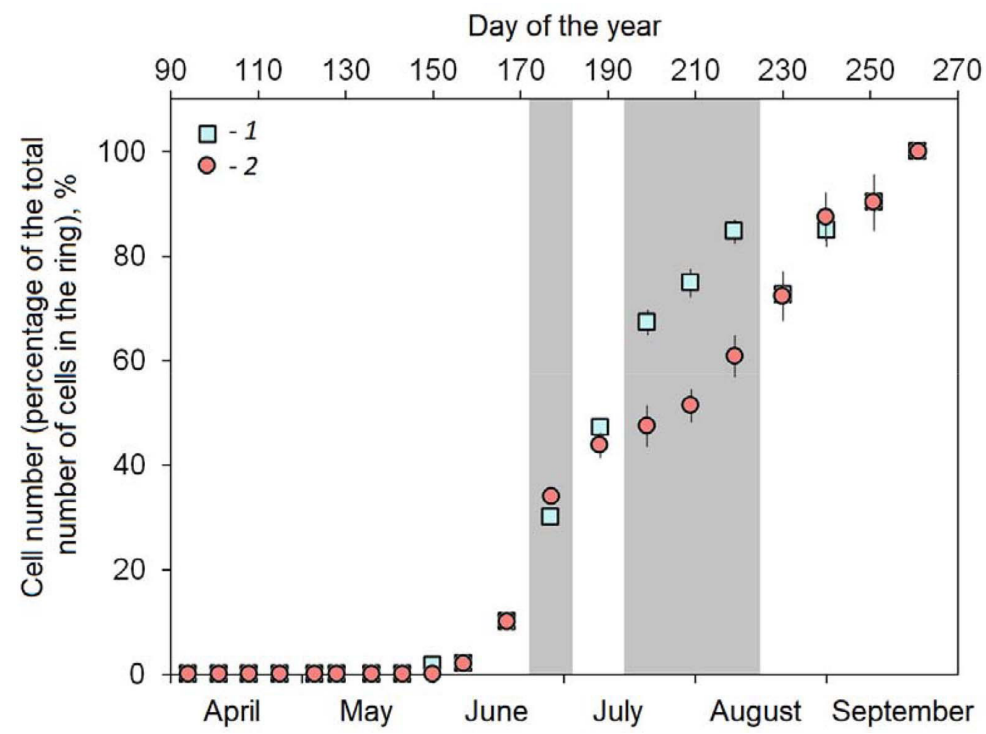

Fig. 3. Cell number dynamics ( \pm standard error) within tree rings of 2014: 1 - young trees; 2 - old trees. Gray area shows statistically significant differences $(p<0.05)$ between the trees of two age classes 

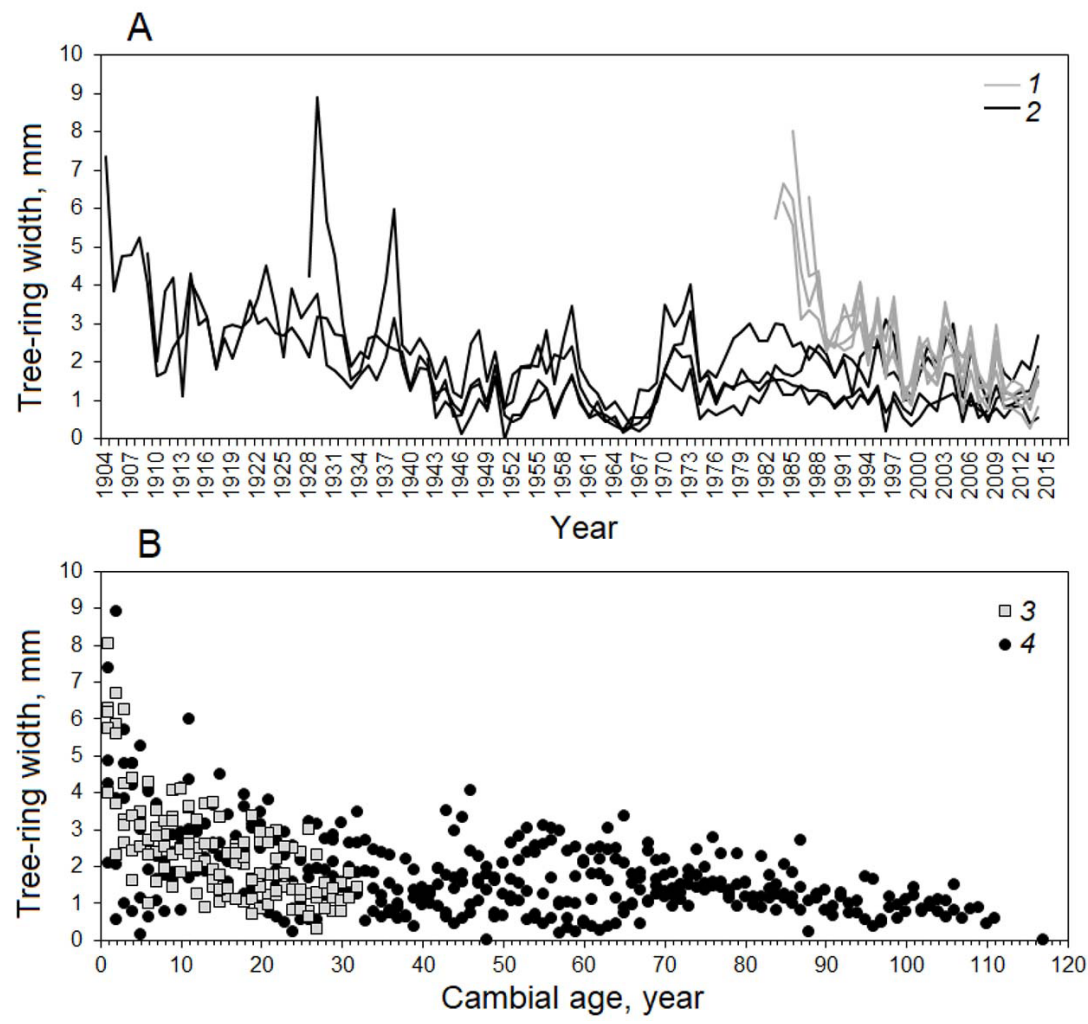

Fig. 4. $A$-individual tree-ring width chronologies of trees, $B$ - tree radial growth relative to the cambial age. 1 , 3 - young trees, 2, 4 - old trees

affected by forest fires, although fires often occur in the pine forests of the Minusinsk Depression in years with low amounts of precipitation in the spring following a low-snow winter.

In 2014, the tree-ring width in young and old trees was 1.52 and $1.76 \mathrm{~mm}(p=0.399)$, with the average cell number of 46 and 52, respectively. The intra-annual variability of the cell radial diameter in young and old trees showed similar patterns, with $45 \mu \mathrm{m}$ sized tracheids in the first part of the ring and a uniform decrease towards the ring boundary (Fig. 5A). The cell-wall thickness showed statistically significant differences between the groups, which are more clearly seen in the standardized tracheidograms (Fig 5B, C). Cell-wall thickness was higher in the young trees in the second part of earlywood and transition zones (positions 8-12 of the tracheidogram, $p<0.10$ ), with the maximum CWT reaching $6.2 \mu \mathrm{m}$ in the young trees compared with $5.5 \mu \mathrm{m}$ in the old trees. In addition, cell-wall thickening occurred when the difference between the integrated growth rates in the two age groups was the greatest (Fig. 3).

\section{Discussion}

Based on the climate data, 2014 was one of the most favorable years in the last few decades for the study area (Tychkov et al., 2019). The Scots pine xylogenesis dynamics was consistent with the data previously reported for other conifer species in the boreal zone (Rossi et al., 2008; Bryukhanova et al., 2013). The maximum cell number in the enlargement zone matched the highest level of the cambial activity and corresponded to the longest sunshine duration 

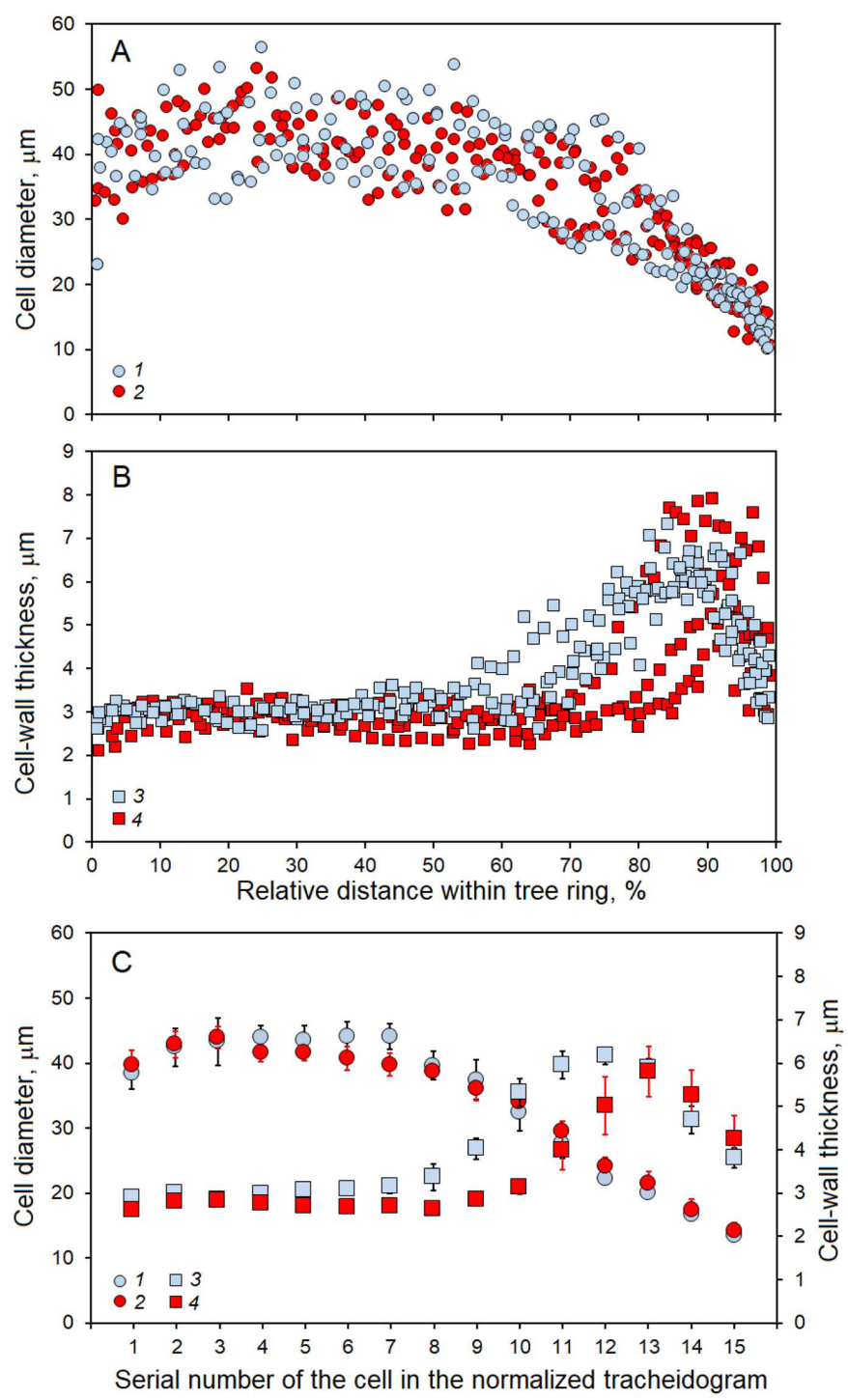

Fig. 5. Cell radial diameter $(A)$ and cell-wall thickness $(B)$ within pine tree rings formed in 2014 and $(C)$ standardized tracheidogram of both anatomical parameters: 1,3 -young trees; 2, 4 - old trees. Thin vertical lines indicate the standard error

and highest rate of photosynthesis and production of assimilates (Vaganov et al., 2006). The nonsignificant differences in the number of cells in the cambial zone between the young and the old trees resulted in the similar tree ring widths and numbers of tracheids produced. The delay of the cell enlargement and cell-wall thickening noted in the old trees was reflected in differences in the cell-wall thickness but not in the cell radial diameter. Based on the results obtained in this study, the maximal cell number in the zones of wall thickening and mature cells was observed in August for the young trees and in September for the old trees. As it has been reported that cell-wall thickening can take place for up to 45-50 days in the old pine trees (Vaganov, Shashkin, 2000), the kinetics of cell-wall thickening could be assumed not only to start later, but also to have a lower rate. Detailed measurements and special experiments are needed to see whether this difference results 
from a lack of assimilates for biosynthesis of the cell wall or from the competition for assimilates between tracheid differentiation processes (Carteni et al., 2018). However, the differences in the physiological processes (photosynthesis, transpiration, discrimination of carbon isotopes) and in the accumulation and redistribution of assimilates during the growing season, which affect the stem growth rate and productivity of both groups, may also be associated with their age (Meinzer et al., 2011). Indeed, as noted above, young trees grow at a fast rate, whereas mature and old trees may have more conservative growth strategy (Vieira et al., 2009). In addition, the direct influence of exogenous factors, such as solar radiation, on the growth of Scots pine and the anatomical structure of its annual rings can be modified by the canopy position of the tree (Kishchenko, 2015). As under natural (nonexperimental) conditions, it is rather difficult to separate the influence of the tree size from the effect of its age on stem growth, this might be the next step of a complex xylogenesis study in evenand uneven-aged forests.

In addition, a thinner cell wall means less carbon accumulation in the stem of a woody plant. Consequently, faster seasonal growth of the young trees in the study area also implies accumulation of greater carbon mass per unit of wood volume. This may be another argument in favor of formation of young stands as potential sink for atmospheric carbon dioxide (Zhou et al., 2015).

\section{Conclusion}

The data obtained in this study could not confirm the definitive effect of tree age on the timing and duration of various phases of wood formation. Research addressing differences in the xylogenesis between the trees of different age groups should take into account the tree vigor and social status, the possible level of competition, and other factors that might limit tree growth. Longterm changes in annual radial growth of the trees of this species and the duration of the juvenile period also play an important role. Despite the similar duration of the growing season (160 days) of both young and old trees, the delay in some developmental phases of older trees compared to the younger ones suggests potential time shift in recording of the climatic signal by the numerous tree-ring parameters. This assumption may be confirmed in the future by the dendroclimatic analysis. The data on the onset and duration of the cambial activity, the dynamics of seasonal cell production, cell extension, and cell-wall thickening in young and old pine trees can be used in the future as input parameters for the VS-model (Vaganov, Shashkin, 2000). This will provide biologically supported values as benchmarks for simulated values of both the annual growth and xylem anatomical structure (tracheidogram).

\section{Acknowledgements / Благодарности}

The reported study was funded by the RFBR, project number 17-04-00610-a.

Исследование выполнено при финансовой поддержке РФФИ, проект 17-04-00610-а.

\section{References / Список литературы}

Antonova G.F., Stasova V.V. (1997) Effect of environmental factors on wood formation in larch (Larix sibirica Ldb.) stems. Trees - Structure and Function, 11(8): 462-468

Babushkina E.A., Belokopytova L.V., Zhirnova D.F., Vaganov E.A. (2019) Siberian spruce tree ring anatomy: imprint of development processes and their high-temporal environmental regulation. Dendrochronologia, 53: 114-124 
Bryukhanova M.V., Kirdyanov A.V., Prokushkin A.S., Silkin P.P. (2013) Specific features of xylogenesis in Dahurian larch, Larix gmelinii (Rupr.) Rupr., growing on permafrost soils in Middle Siberia. Russian Journal of Ecology, 44(5): 361-366

Campelo F., Vieira J., Battipaglia G., de Luis M., Nabais C., Freitas H., Cherubini P. (2015) Which matters most for the formation of intra-annual density fluctuations in Pinus pinaster: age or size? Trees - Structure and Function, 29(1): 237-245

Carteni F., Deslauriers A., Rossi S., Morin H., De Micco V., Mazzoleni S., Giannino F. (2018) The physiological mechanisms behind the earlywood-to-latewood transition: a process-based modelling approach. Frontiers in Plant Science, 9: 1053

Churakova (Sidorova) O.V., Shashkin A.V., Siegwolf R.T.W., Spahni R., Launois T., Saurer M., Bryukhanova M.V., Benkova A.V., Kuptsova A.V., Peylin P., Vaganov E.A., Masson-Delmotte V., Roden J. (2016) Application of eco-physiological models to the climatic interpretation of $\delta^{13} \mathrm{C}$ and $\delta^{18} \mathrm{O}$ measured in Siberian larch tree-rings. Dendrochronologia, 39: 51-59

Connor K.F., Lanner R.M. (1990) Effects of tree age on secondary xylem and phloem anatomy in stems of Great Basin bristlecone pine (Pinus longaeva). American Journal of Botany, 77(8): $1070-1077$

Cuny H.E., Rathgeber C.B.K., Frank D., Fonti P., Mäkinen H., Prislan P., Rossi S., del Castillo E.M., Campelo F., Vavrcik H., Camarero J.J., Bryukhanova M.V., Jyske T., Gricar J., Gryc V., De Luis M., Vieira J., Cufar K., Kirdyanov A.V., Oberhuber W., Treml V., Huang J.-G., Li X., Swidrak I., Deslauriers A., Liang E., Nojd P., Gruber A., Nabais C., Morin H., Krause C., King G., Fournier M. (2015) Woody biomass production lags stem-girth increase by over one month in coniferous forests. Nature Plants, 1(11): 15160

Denne M.P. (1989) Definition of latewood according to Mork (1928). IAWA Bulletin, 10(1): 59-62

Fonti M.V., Vaganov E.A., Wirth C., Shashkin A.V., Astrakhantseva N.V., Schulze E.-D. (2018) Age-effect on intra-annual $\delta^{13} \mathrm{C}$-variability within Scots pine tree-rings from Central Siberia. Forests, 9(6): 364

Holmes R.L. (2001) Dendrochronology Program Library, Version 2001. Laboratory of Tree-Ring Research, University of Arizona, Tucson, Arizona USA

Kishchenko I.T. (2014) Seasonal growth of differently aged Picea abies L. (Karst.) trees in Northern Karelia. Bulletin of Higher Educational Institutions. Russian Forestry Journal [Izvestiya vysshikh uchebnykh zavedenii. Lesnoi zhurnal], 2: 46-51 (in Russian)

Kishchenko I.T. (2015) Anatomical structure of tree rings Pinus sylvestris L. of different age and the position within the forest canopy of taiga zone. Conifers of the Boreal Zone [Hvojnye boreal'noj zony], 33(5-6): 217-220 (in Russian)

Kostyakova T.V., Touchan R., Babushkina E.A., Belokopytova L.V. (2018) Precipitation reconstruction for the Khakassia region, Siberia, from tree rings. Holocene, 28(3): 377-385

Lobzhanidze E.D. (1961) Cambium and tree ring formation. Tbilisi, AS GSSR, 156 p. (in Russian)

Meinzer F.C., Lachenbruch B., Dawson T.E. (2011) Size- and age-related changes in tree structure and function. Dordrecht, The Netherlands, Springer, $514 \mathrm{p}$.

Popkova M.I., Vaganov E.A., Shishov V.V., Babushkina E.A., Rossi S., Fonti M.V., Fonti P. (2018) Modeled tracheidograms disclose drought influence on Pinus sylvestris tree-rings structure from Siberian forest-steppe. Frontiers in Plant Science, 9: 1144 
Rathgeber C.B.K., Rossi S., Bontemps J.D. (2011) Cambial activity related to tree size in a mature silver-fir plantation. Annals of Botany, 108(3): 429-438

Rinn F. (1996) TSAP V 3.6 Reference manual: computer program for tree-rings analysis and presentation. Heidelberg, Frank Rinn Distribution, 264 p.

Rinne K.T., Saurer M., Kirdyanov A.V., Loader N.J., Bryukhanova M.V., Werner R.A., Siegwolf R.T.W. (2015) The relationship between needle sugar carbon isotope ratios and tree rings of larch in Siberia. Tree Physiology, 35(11): 1192-1205

Rossi S., Deslauriers A., Anfodillo T., Carrer M. (2008) Age-dependent xylogenesis in timberline conifers. New Phytologist, 177(1): 199-208

Steppe K., Sterck F., Deslauriers A. (2015) Diel growth dynamics in tree stems: Linking anatomy and ecophysiology. Trends in Plant Science, 20(6): 335-343

Tychkov I.I., Sviderskaya I.V., Babushkina E.A., Popkova M.I., Vaganov E.A., Shishov V.V. (2019) How can the parameterization of a process-based model help us understand real tree-ring growth? Trees - Structure and Function, 33(2): 345-357

Vaganov E.A. (1990) The tracheidogram method in tree-ring analysis and its application. Methods of dendrochronology. Applications in the environmental sciences. Cook E.R., Kairiukstis L.A. (eds.) Dordrecht, Kluwer Academic Publishers, p. 63-75

Vaganov E.A., Hughes M.K., Shashkin A.V. (2006) Growth dynamics of conifer tree rings: images of past and future environments. Springer, Berlin, Heidelberg, $358 \mathrm{p}$.

Vaganov E.A., Shashkin A.V. (2000) Growth and structure of conifer tree rings. Novosibirsk, Nauka, 232 p. (in Russian)

Vieira J., Campelo F., Nabais C. (2009) Age-dependent responses of tree-ring growth and intraannual density fluctuations of Pinus pinaster to Mediterranean climate. Trees - Structure and Function, 23(2): 257-265

Vieira J., Carvalho A., Campelo F. (2018) Xylogenesis in the early life stages of maritime pine. Forest Ecology and Management, 424: 71-77

Zhou T., Shi P., Jia G., Dai Y., Zhao X., Shangguan W., Du L., Wu H., Luo Y. (2015) Agedependent forest carbon sink: Estimation via inverse modeling. Journal of Geophysical ResearchBiogeosciences, 120(12): 2473-2492 